\title{
Study on Hydraulic Performance of Drip Irrigation System under Field Condition
}

\author{
H. P. Ajay Kumar* and H. G. Ashoka \\ College of Agricultural Engineering, UAS, GKVK, Bengaluru - 560065, Karnataka, India \\ *Corresponding author
}

Keywords

Inline drip emitter,

Drip irrigation,

Hydraulic

parameters,

Emission

uniformity

Article Info

Accepted:

08 January 2020

Available Online:

10 February 2020

A B S T R A C T

A field study was undertaken to evaluate the performance of 4 lph capacity inline drip emitter in farmer's field at $0.75 \mathrm{~kg} / \mathrm{cm}^{2}$ and $1.00 \mathrm{~kg} / \mathrm{cm}^{2}$ operating pressure. The efficient water application through drip irrigation is mainly depends upon the hydraulic parameters of the system, which includes the effect of pressure on coefficient of manufacturer variation, emitter flow variation, emission uniformity, uniformity coefficient, application efficiency and distribution efficiency. The results of the hydraulic parameters evaluation revealed that the coefficient of manufacturer variation, emission uniformity, uniformity coefficient, application efficiency and distribution efficiency were found to be excellent at both 0.75 and $1.00 \mathrm{~kg} / \mathrm{cm}^{2}$ operating pressure for all the farmers' fields. However, among the farmers field, emitter flow variation was observed to be in only for $33.33 \%$ farmers' fields at $1.00 \mathrm{~kg} / \mathrm{cm}^{2}$ operating pressure and it was not acceptable at $0.75 \mathrm{~kg} / \mathrm{cm}^{2}$ for all the farmers' fields.

\section{Introduction}

Drip irrigation system is defined as "an irrigation which maximises the application efficiency of water and fertilizer by allowing water drop by drop to the root zone of plants, either in to the soil surface or directly in to the root zone, through a network system of valves, pipes, tubing and emitters". The objective of the drip irrigation is to provide continuous supply of water to each plant to meet the requirement of water for the plant to the healthy growth and to meet the transpiration demands (Karmeli and Keller, 1974). Efficient drip irrigation system needs to be free from suspended materials, organic matter, sand and clay and it is achieved by installing the different types of filters. The control valve is installed in the pumping station to maintain the required pressure head for operating the system (Hensen et al., 1980; Bralts and $\mathrm{Wu}, 1979)$.

The improvement of irrigation water management is becoming critical to increase the efficiency of irrigation water use and to 
reduce water losses. Drip irrigation evaluation in the field under a set of operating conditions is very important to ensure the desired discharge to all the growing crops.

A best and desirable feature of trickle irrigation is the uniform distribution of water and it is governed by proper design, management and adoption of the system. Ideally, a well-designed system applies nearly equal amount of water to each plant to meets its water requirements in addition to rational design and economics. The causes of the irrigation discharge variations are mainly due to manufacturing variations, pressure differences, emitter plugging, aging, frictional head losses, change in irrigation water temperature and the emitter sensitivity results in flow rate variations even between two identical emitters (Mizyed and Kruse, 2008)

\section{Materials and Methods}

\section{Experimental site}

The present study was carried out during 2017-18 in the farmer's field of different villages of Nelamangala, Devanahalli, Doddaballapura and Hosakote taluks of Bengaluru rural district. There were 15 different irrigating field involved for the study.

Hydraulic parameters for drip irrigation system

\section{Discharge of emitters}

The study was conducted in the farmers' fields having a 4 lph dripper spaced at $40 \mathrm{~cm}$ on laterals. The distribution of water application and discharges from emitters along the lateral are measured using ASAE Standards. The procedure was based on measurements of emitter discharge like;
The four lateral lines were selected on a sub main - one at the inlet, one at the far end and the two in the middle which was at the onethird and two-thirds positions.

The four dripper positions were tested on each lateral - one at the inlet, one at the far end and the two in the middle which was at the onethird and two-thirds positions.

Therefore, there were 16 measurement positions used for the study. The discharge was measured by collecting the water from individual drippers using measuring cylinders. The discharge was collected for ten minutes period and continued for different pressure ranges like $0.75 \mathrm{~kg} / \mathrm{cm}^{2}$ and $1 \mathrm{~kg} / \mathrm{cm}^{2}$. The procedure was repeated thrice and the average of the volume of the water was considered as the discharge for a particular position (Capra and Scieotone, 1998).

\section{Coefficient of Manufacturer's Variation $\left(\mathbf{C}_{\mathrm{v}}\right)$}

Coefficient of manufacturer's variation is definedastheratioofthestandarddeviationofflo wtothemeanflowforasamplenumberofemitters (Keller and Karmeli, 1974). Coefficient of manufacturer's variation is a statistical parameter and expressed as:

$\mathrm{C}_{\mathrm{v}}=\frac{s_{d}}{\text { qave }} * 100$

Where,

$S_{d}=$ standard deviation of flow

$$
=\sqrt{\frac{\left(q_{1}^{2}+q_{2}^{2}+q_{n}^{2}+q_{n}^{2}-n q_{a v e}^{n}\right)}{(n-1)}}
$$

$\mathrm{q}_{\mathrm{ave}}=$ mean flow for a sampled number of emitters 


\begin{tabular}{|c|c|c|}
\hline \multicolumn{3}{|l|}{$\underline{q 1+q 2+}$} \\
\hline \multicolumn{3}{|c|}{$\begin{array}{l}q 1, q 2, q 3, q n=\text { are the discharges } \\
\text { tested }\end{array}$} \\
\hline \multicolumn{3}{|c|}{$\begin{array}{l}\text { The recommended classifi } \\
\text { manufacturer's coefficient of vari } \\
\text { ASAE are; }\end{array}$} \\
\hline $\begin{array}{c}\text { Emitter } \\
\text { type }\end{array}$ & $\begin{array}{c}\text { Cv range } \\
(\%)\end{array}$ & Classificatio \\
\hline \multirow{4}{*}{$\begin{array}{l}\text { Poin } \\
\text { Source }\end{array}$} & $<5$ & Good \\
\hline & 5 to 10 & Average \\
\hline & 10 to 15 & Marginal \\
\hline & $>15$ & Unaccepted \\
\hline \multirow{3}{*}{$\begin{array}{l}\text { Line } \\
\text { Source }\end{array}$} & $<10$ & Good \\
\hline & 10 to 20 & Average \\
\hline & $>20$ & Marginal \\
\hline
\end{tabular}

\section{Emission Uniformity (Eu)}

TheEUduringthefieldtestistheratioexpressedas apercentageofaverageemitterdischargefromthe lower1/4thofemitter to the average discharge of all the emitters of the drip system (Burt et al., 1997). The average of lowest $1 / 4^{\text {th }}$ of emitter was selected as a practical value for minimum discharge, as recommended by the United States soil conservation services for field evaluation of irrigation systems and is expressed by the equation.

$$
E U=\frac{q_{m}}{q_{a}} * 100
$$

Where,

$\mathrm{EU}=$ the field test emission uniformity, percentage

$\mathrm{q}_{\mathrm{m}}=$

average of the lowest $1 / 4^{\text {th }}$ of the field data emitter discharge, lph

$q_{\mathrm{a}}=$ average of all the field data emitter discharge, (lph)

The Recommended classification of emission uniformity as per ASAE are;

\begin{tabular}{|l|l|}
\hline EU range & Ratings \\
\hline $\mathbf{9 0 \%}$ or greater & Excellent \\
\hline $\mathbf{8 0}$ to $90 \%$ & Good \\
\hline $\mathbf{7 0}$ to $80 \%$ & Fair \\
\hline Less than $70 \%$ & Poor \\
\hline
\end{tabular}

\section{Emitter flow variation}

The second method of field evaluation of emission uniformity relies on the design procedure based on estimating emitter flow variation (Wu and Gitlin, 1973 and 1974). It consists of finding the minimum and maximum pressure in the sub-units and the emitter flow variation (Qvar) was worked out using the following equation.

$\mathrm{Q}_{\mathrm{var}}=100\left[1-\frac{Q_{\min }}{Q_{\max }}\right]$

Where,

$\mathrm{Q}_{\mathrm{var}}=$ emitter flow variation in percentage

$\mathrm{Q}_{\text {min }}=$ minimum emitter discharge rate in the system, lph

$\mathrm{Q}_{\max }=$ average or design emitter discharge rate, $1 \mathrm{ph}$

General criteria for Qvar values are 10 per cent or less (desirable) and 10 to 20 per cent Acceptable and greater than 25 per cent Not Acceptable.

\section{Uniformity coefficient (UC)}

The uniformity coefficient was worked out using Bralts and Kesner, (1982) equation.

$$
\begin{aligned}
& \mathrm{UC}=100\left(1-\mathrm{V}_{\mathrm{q}}\right)=100\left(1-\frac{\frac{s_{d}}{q_{a}}}{q_{a}}\right) \\
& \text { Where, } \\
& \mathrm{UC}=\text { Statistical uniformity coefficient }(\%) \\
& \mathrm{Vq}=\text { coefficient of variation emitter flow } \\
& \mathrm{Sq}=\text { standard deviation of emitter flow }
\end{aligned}
$$


qa $=$ mean emitter flow rate, $\mathrm{lph}$

Recommended classification of uniformity coefficient as per ASAE are;

\begin{tabular}{|l|l|}
\hline UC range & Ratings \\
\hline $\mathbf{9 0 \%}$ or & Excellent \\
\hline $\mathbf{8 0}$ to $90 \%$ & Very good \\
\hline $\mathbf{7 0}$ to $80 \%$ & Fair \\
\hline $\mathbf{6 0}$ to $70 \%$ & Poor \\
\hline Less than & Unacceptable \\
\hline
\end{tabular}

\section{Distribution efficiency $\left(E_{d}\right)$}

The distribution efficiency determine show uniformly irrigation water can be distributed through a drip irrigation system into the field. It can be determined from the emitter flow variation along a lateral line in a drip irrigation system layout in the field and can be expressed by the equation,

$$
\mathrm{E}_{\mathrm{d}}=100 *\left[1-\frac{\Delta \mathrm{q}_{a}}{q_{m}}\right]
$$

Where,

$\mathrm{Ed}=$ distribution efficiency in percentage $\mathrm{qm}=$ mean emitter flow rate, $1 \mathrm{ph}$

$\Delta q a=$ average absolute deviation of each emitter flow from the mean emitter flow

$$
\begin{aligned}
\Delta_{\mathrm{q}_{\mathrm{a}}}=\left[\frac{q_{r}-q_{\text {ave }}}{q_{\text {ave }}}\right] & * 100 \\
\mathrm{q}_{\mathrm{r}} & =\text { rated flow, lph } \\
\mathrm{q}_{\mathrm{avg}} & =\text { Average emitter flow rate, }
\end{aligned}
$$

\section{Application efficiency $\left(\mathbf{E}_{\mathbf{a}}\right)$}

The application efficiency is defined as the ratio of water required in the root zone to the total amount of water applied. It shows how well irrigation water is applied that is, what percentage of water applied is stored in the root zone as required and is available for plantuse (Mane et al., 2018)

The water required in the root zone is assumed to be applied at the minimum flow rate and over the total irrigation time. Therefore, application efficiency can be expressed as,

$\mathrm{E}_{\mathrm{a}}=\frac{N \cdot Q_{\min T} T}{V w} \times 100$

Where,

lph

$$
\begin{aligned}
& \mathrm{Ea}=\text { application efficiency, } \% \\
& \mathrm{~N}=\text { total number of emitter } \\
& \mathrm{Q}_{\text {min }}=\text { minimum emitter flow rate, }
\end{aligned}
$$

$$
\mathrm{T}=\text { total irrigation time, }
$$

$\mathrm{V}_{\mathrm{w}}=$ total volume of water applied, 1

Since, the mean emitter flow (Qavg) is,

Qavg $=\frac{V w}{N \cdot T}$

The application efficiency can also be expressed as,

$\mathrm{E}_{\mathrm{a}}=\frac{Q_{\min }}{Q_{\text {avg }}} * 100$

Where,

Qmin = minimum emitter flow rate, $1 \mathrm{ph}$

Qavg $=$ average emitter flow rate, $1 \mathrm{ph}$

\section{Results and Discussion}

Drip irrigation system was operated under different operating pressures to study the different hydraulic parameters of drip irrigation system. For this purpose, drip irrigation discharges were measured at different operating pressures for $4 \mathrm{lph}$ emitter discharge. The Average Emitter flow rate of $3.67 \mathrm{lph}$ was found to be maximum at 1.00 $\mathrm{kg} / \mathrm{cm}^{2}$ operating pressure in $\mathrm{F} 2$ fields and a minimum of $2.15 \mathrm{lph}$ at $0.75 \mathrm{~kg} / \mathrm{cm}^{2}$ operating pressure in F14 fields (Table 5). 
The coefficient of manufacturer variation of 0.0549 and emitter flow variation of $47.75 \%$ was found maximum at $0.75 \mathrm{~kg} / \mathrm{cm}^{2}$ operating pressure for $\mathrm{F} 15$ and $\mathrm{F} 7$ fields. It was minimum of 0.0123 and $17.12 \%$ at 1.0 $\mathrm{kg} / \mathrm{cm}^{2}$ operating pressure for $\mathrm{F} 2$ and $\mathrm{F} 1$ fields (Table 1 and 2). Thus, for a particular spacing, coefficient of variation and emitter flow variation and operating pressure having inverse relation for all emission devices. To decide whether the system is good, average, marginal and excellent, it is necessary to determine the manufactures coefficient of variation either for point source or line source. It is observed that, $\mathrm{C}_{\mathrm{v}}$ for $4 \mathrm{lph}$ discharge of drippers comes under the range of classification as good for both the operating pressure.

The $Q_{\text {var }}$ is acceptable at $1.00 \mathrm{~kg} / \mathrm{cm}^{2}$ operating pressure for F1, F2, F3, F4 and F6 fields. However, it is not acceptable at 0.75 $\mathrm{kg} / \mathrm{cm}^{2}$ for all the fields. From the Table 1 and 2 , it is evident that when the operating pressure of drip irrigation system is higher, coefficient of manufacturer variation and emitter flow variation is lower and therefore the pressure directly affect the discharge rate of emitter.

Emission uniformity of the system decides the uniformity distribution of discharge by each emitter or uniformity distribution of water to each crop. The emission uniformity of $98.73 \%$ and the uniformity coefficient of $98.68 \%$ for $4 \mathrm{lph}$ emitter were found to be maximum at $1.0 \mathrm{~kg} / \mathrm{cm}^{2}$ operating pressure for F1 and F3 fields. While it is minimum of $92.79 \%$ and $94.15 \%$ at $0.75 \mathrm{~kg} / \mathrm{cm}^{2}$ operating pressure for F15 field (Table 3 and 4). It is observed that EU and UC for 4 lph discharge of drippers comes under the range of classification as excellent for both the operating pressure. Thus, for a particular spacing, emission uniformity and uniformity coefficient increases as the operating pressure increases for all irrigation systems. The emission uniformity increases due to increase in the ratio of the minimum rate of discharge to the average rate of discharge. At a particular spacing emission uniformity (EU) increases due to constant emitter point throughout the lateral length.

Table.1 Coefficient of Manufacturer variation $\left(\mathrm{C}_{\mathrm{v}}\right)$ under different operating pressure

\begin{tabular}{|c|c|c|c|c|}
\hline \multirow{2}{*}{ Field No. } & \multicolumn{2}{|c|}{ Coefficient of Manufacturer variation $\left(\mathbf{C}_{\mathbf{v}}\right) \mathbf{( \% )}$} & \multicolumn{2}{|c|}{ Classification } \\
\cline { 2 - 5 } & $\mathbf{0 . 7 5}\left(\mathbf{k g} / \mathbf{c m}^{\mathbf{2}}\right)$ & $\mathbf{1 . 0 0}\left(\mathbf{k g} / \mathbf{c m}^{\mathbf{2}}\right)$ & $\mathbf{0 . 7 5} \mathbf{( k g / \mathbf { c m } ^ { 2 } )}$ & $\mathbf{1 . 0 0}\left(\mathbf{k g} / \mathbf{c m}^{\mathbf{2}}\right)$ \\
\hline F1 & 0.0268 & 0.0183 & Good & Good \\
\hline F2 & 0.0280 & 0.0123 & Good & Good \\
\hline F3 & 0.0290 & 0.0132 & Good & Good \\
\hline F4 & 0.0301 & 0.0238 & Good & Good \\
\hline F5 & 0.0523 & 0.0360 & Good & Good \\
\hline F6 & 0.0344 & 0.0274 & Good & Good \\
\hline F7 & 0.0405 & 0.0311 & Good & Good \\
\hline F8 & 0.0237 & 0.0197 & Good & Good \\
\hline F9 & 0.0226 & 0.0195 & Good & Good \\
\hline F10 & 0.0368 & 0.0300 & Good & Good \\
\hline F11 & 0.0490 & 0.0469 & Good & Good \\
\hline F12 & 0.0325 & 0.0317 & Good & Good \\
\hline F13 & 0.0343 & 0.0168 & & Good \\
\hline F14 & 0.0290 & 0.0238 & 0.0379 & \\
\hline F15 & 0.0549 & & & \\
\hline
\end{tabular}


Table.2 Emitter flow variation $\left(\mathrm{Q}_{\text {var }}\right)$ under different operating pressure

\begin{tabular}{|c|c|c|c|c|}
\hline \multirow{2}{*}{ Field No. } & \multicolumn{2}{|c|}{ Emitter flow variation $\left(\mathbf{Q}_{\mathbf{v a r}}\right) \mathbf{( \% )}$} & \multicolumn{2}{|c|}{ Classification } \\
\cline { 2 - 5 } & $\mathbf{0 . 7 5}\left(\mathbf{k g} / \mathbf{c m}^{\mathbf{2}}\right)$ & $\mathbf{1 . 0 0}\left(\mathbf{k g} / \mathbf{c m}^{\mathbf{2}}\right)$ & $\mathbf{0 . 7 5}\left(\mathbf{k g} / \mathbf{c m}^{\mathbf{2}}\right)$ & $\mathbf{1 . 0 0}\left(\mathbf{k g} / \mathbf{c m}^{\mathbf{2}}\right)$ \\
\hline F1 & 26.87 & 17.12 & Not Acceptable & Acceptable \\
\hline F2 & 35.31 & 23.69 & Not Acceptable & Acceptable \\
\hline F3 & 34.28 & 25.00 & Not Acceptable & Acceptable \\
\hline F4 & 34.00 & 25.00 & Not Acceptable & Acceptable \\
\hline F5 & 33.48 & 30.43 & Not Acceptable & Not Acceptable \\
\hline F6 & 29.50 & 23.13 & Not Acceptable & Acceptable \\
\hline F7 & 47.75 & 34.37 & Not Acceptable & Not Acceptable \\
\hline F8 & 37.65 & 27.01 & Not Acceptable & Not Acceptable \\
\hline F9 & 34.00 & 27.81 & Not Acceptable & Not Acceptable \\
\hline F10 & 41.70 & 36.31 & Not Acceptable & Not Acceptable \\
\hline F11 & 41.00 & 34.56 & Not Acceptable & Not Acceptable \\
\hline F12 & 37.60 & 29.71 & Not Acceptable & Not Acceptable \\
\hline F13 & 43.25 & 27.68 & Not Acceptable & Not Acceptable \\
\hline F14 & 47.12 & 33.56 & Not Acceptable & Not Acceptable \\
\hline F15 & 39.43 & 28.50 & Not Acceptable & Not Acceptable \\
\hline
\end{tabular}

Table.3 Emission Uniformity under different operating pressure

\begin{tabular}{|c|c|c|c|c|}
\hline \multirow[t]{2}{*}{ Field. No. } & \multicolumn{2}{|c|}{ Emission uniformity (EU) (\%) } & \multicolumn{2}{|c|}{ Classification } \\
\hline & $0.75\left(\mathrm{~kg} / \mathrm{cm}^{2}\right)$ & $1.00\left(\mathrm{~kg} / \mathrm{cm}^{2}\right)$ & $0.75\left(\mathrm{~kg} / \mathrm{cm}^{2}\right)$ & $1.00\left(\mathrm{~kg} / \mathrm{cm}^{2}\right)$ \\
\hline F1 & 95.93 & 98.73 & Excellent & Excellent \\
\hline F2 & 95.54 & 98.24 & Excellent & Excellent \\
\hline F3 & 95.69 & 97.20 & Excellent & Excellent \\
\hline F4 & 94.63 & 98.68 & Excellent & Excellent \\
\hline F5 & 95.18 & 98.03 & Excellent & Excellent \\
\hline F6 & 94.79 & 97.55 & Excellent & Excellent \\
\hline F7 & 94.19 & 96.69 & Excellent & Excellent \\
\hline F8 & 94.01 & 97.55 & Excellent & Excellent \\
\hline F9 & 93.20 & 97.38 & Excellent & Excellent \\
\hline F10 & 94.22 & 97.33 & Excellent & Excellent \\
\hline F11 & 93.09 & 97.69 & Excellent & Excellent \\
\hline F12 & 93.70 & 97.01 & Excellent & Excellent \\
\hline F13 & 93.39 & 97.33 & Excellent & Excellent \\
\hline F14 & 93.38 & 97.79 & Excellent & Excellent \\
\hline F15 & 92.79 & 96.19 & Excellent & Excellent \\
\hline
\end{tabular}


Table.4 Uniformity coefficient (UC) under different operating pressure

\begin{tabular}{|c|c|c|c|c|}
\hline \multirow[t]{2}{*}{ Field. No. } & \multicolumn{2}{|c|}{ Uniformity coefficient (UC) (\%) } & \multicolumn{2}{|c|}{ Classification } \\
\hline & $0.75\left(\mathrm{~kg} / \mathrm{cm}^{2}\right)$ & $1.00\left(\mathrm{~kg} / \mathrm{cm}^{2}\right)$ & $0.75\left(\mathrm{~kg} / \mathrm{cm}^{2}\right)$ & $1.00\left(\mathrm{~kg} / \mathrm{cm}^{2}\right)$ \\
\hline F1 & 97.19 & 98.07 & Excellent & Excellent \\
\hline F2 & 97.02 & 98.77 & Excellent & Excellent \\
\hline F3 & 96.93 & 98.68 & Excellent & Excellent \\
\hline F4 & 96.99 & 97.63 & Excellent & Excellent \\
\hline F5 & 94.76 & 96.45 & Excellent & Excellent \\
\hline F6 & 96.65 & 97.25 & Excellent & Excellent \\
\hline F7 & 95.95 & 96.68 & Excellent & Excellent \\
\hline F8 & 96.93 & 97.62 & Excellent & Excellent \\
\hline F9 & 95.97 & 97.73 & Excellent & Excellent \\
\hline F10 & 95.45 & 96.82 & Excellent & Excellent \\
\hline F11 & 94.48 & 95.10 & Excellent & Excellent \\
\hline F12 & 94.45 & 96.82 & Excellent & Excellent \\
\hline F13 & 96.34 & 98.31 & Excellent & Excellent \\
\hline F14 & 96.94 & 97.61 & Excellent & Excellent \\
\hline F15 & 94.15 & 96.20 & Excellent & Excellent \\
\hline
\end{tabular}

Table.5 Average emitter flow rate, Application efficiency and Distribution efficiency under different operating pressure

\begin{tabular}{|c|c|c|c|c|c|c|}
\hline \multirow[t]{2}{*}{ Field. No } & \multicolumn{2}{|c|}{$\begin{array}{c}\text { Average emitter flow rate } \\
\text { (lph) }\end{array}$} & \multicolumn{2}{|c|}{$\begin{array}{l}\text { Application Efficiency } \\
\left(\mathbf{E}_{\mathrm{a}}\right)(\%)\end{array}$} & \multicolumn{2}{|c|}{$\begin{array}{l}\text { Distribution Efficiency } \\
\left(\mathbf{E}_{\mathbf{d}}\right)(\%)\end{array}$} \\
\hline & $0.75\left(\mathrm{~kg} / \mathrm{cm}^{2}\right.$ & $1.00\left(\mathrm{~kg} / \mathrm{cm}^{2}\right)$ & $0.75\left(\mathrm{~kg} / \mathrm{cm}^{2}\right)$ & $1.00\left(\mathrm{~kg} / \mathrm{cm}^{2}\right)$ & $0.75\left(\mathrm{~kg} / \mathrm{cm}^{2}\right)$ & $1.00\left(\mathrm{~kg} / \mathrm{cm}^{2}\right)$ \\
\hline F1 & 2.97 & 3.38 & 95.71 & 98.73 & 97.93 & 98.45 \\
\hline F2 & 3.02 & 3.67 & 93.70 & 97.04 & 97.90 & 99.11 \\
\hline F3 & 2.66 & 3.02 & 94.61 & 97.83 & 97.64 & 98.95 \\
\hline F4 & 2.73 & 3.04 & 91.80 & 93.34 & 97.52 & 98.03 \\
\hline F5 & 2.66 & 2.96 & 90.31 & 95.84 & 96.85 & 97.60 \\
\hline F6 & 2.74 & 3.12 & 91.95 & 96.15 & 96.67 & 97.05 \\
\hline F7 & 2.49 & 2.72 & 92.77 & 93.92 & 96.44 & 97.62 \\
\hline F8 & 2.50 & 2.96 & 93.24 & 96.61 & 97.36 & 98.15 \\
\hline F9 & 2.64 & 2.98 & 93.02 & 96.83 & 97.38 & 98.05 \\
\hline F10 & 2.37 & 2.59 & 92.48 & 94.64 & 96.53 & 97.59 \\
\hline F11 & 2.43 & 2.68 & 92.68 & 94.93 & 94.33 & 95.73 \\
\hline F12 & 2.54 & 2.90 & 93.00 & 94.90 & 96.55 & 97.72 \\
\hline F13 & 2.33 & 2.92 & 93.96 & 97.06 & 96.12 & 98.64 \\
\hline F14 & 2.15 & 2.71 & 93.46 & 95.59 & 97.65 & 98.21 \\
\hline F15 & 2.55 & 3.18 & 93.91 & 95.25 & 92.73 & 96.78 \\
\hline
\end{tabular}


The application efficiency $\left(\mathrm{E}_{\mathrm{a}}\right)$ and distribution efficiency $\left(E_{d}\right)$ of drip irrigation system is estimated for $4 \mathrm{lph}$ emitters under different operating pressure. The application efficiency of $98.73 \%$ and distribution efficiency of $99.11 \%$ found to be maximum at $1.0 \mathrm{~kg} / \mathrm{cm}^{2}$ operating pressure for $\mathrm{F} 1$ and $\mathrm{F} 2$ fields and minimum of $90.31 \%$ and $92.73 \%$ at $0.75 \mathrm{~kg} / \mathrm{cm}^{2}$ operating pressure for F5 and F15 fields (Table 5). Thus, for a particular spacing, application efficiency and distribution efficiency increases with the increased pressure of the operating system for all irrigation systems. The results are in conformity with the findings of Popale et al., (2011), SAFI et al., (2007) and Kumar and Singh (2007).

In conclusion, a study was conducted to evaluate the performance of drip irrigation system under different operating pressure. Itwas observed that at a particular spacing, the emission uniformity, uniformity coefficient, application efficiency and distribution efficiency increased with increase in operating pressure. While coefficient of variation and emitter flow variation were decreased for all farmers field. By considering all the above calculated hydraulic parameters, only $5(33.33 \%)$ farmers field showed a better hydraulic efficiency (Emmittor flow variation) by meeting the standards set by ASCE.

\section{References}

Bralts V F; Kesner C D. 1982. Drip irrigation field uniformity estimation. Transactions of the American Society of Agricultural Engineers, 26: 1369-1374.

Bralts V F; Wu I P. 1979. Emitter flow variation and uniformity for drip irrigation. St. Joseph Mich., ASAE.

Capra S; Scieotone H. 1998. Water quality and distribution uniformity in drip/trickle irrigation systems. Journal of Agricultural Engineering Research,70: 355-365.

Hema Krishna. 2009. Study of hydraulic parameters of drip irrigation systems in farmers' fields under different crops. M.Tech Thesis (Unpub), Acharya N. G. Ranga Agricultural University

Hensen V E; Israelson O W; Stringham G E. 1980. Irrigation Principals and Practices. Wiley International ed., New York.

Karmeli D; Keller J. 1974. Trickle Irrigation Design. Rain Birdsprinkling Manufacturing Corporation, Glendora, California, 130-132.

Keller J; Bliesner R D. 1990. Sprinkle and Trickle Irrigation. Van Nostrand Reinhold. New York, 3(5), 86-96.

Kumar S; Singh, P. 2007. Evaluation of hydraulic performance of drip irrigation system. Journal of Agricultural Engineering, 44(2).

Mane M S; Ayare B L; S S Magar. 2008, Principal of Drip Irrigation System. Jain brothers. Karnataka, 80-130.

Popale PG; Bombale V T; Magar AP.2011. Hydraulic Performance of Drip Irrigation System. Engineering and Technology in India, 2 (1\&2): 24-28.

Safi B; Neyshabouri M R; Nuzemi A H; Massina S; Mirlatifi S M. 2007. Water application uniformity of a sub-surface drip irrigation system at various operating pressure and tape lengths. Turkish J. Agric.31: 275-285.

Wu I P; Gitlin H M. 1973. Hydraulics and uniformity for drip irrigation. J. Irrig. Drain. Div. Proc. ASCE, 99 (2): 157-168.

\section{How to cite this article:}

Ajay Kumar, H. P. and Ashoka, H. G. 2020. Study on Hydraulic Performance of Drip Irrigation System under Field Condition. Int.J.Curr.Microbiol.App.Sci. 9(02): 626-633.

doi: https://doi.org/10.20546/ijcmas.2020.902.077 